\title{
Feasibility of Measurement and Adherence to System Performance Measures for Rheumatoid Arthritis in 5 Models of Care
}

\author{
Claire E.H. Barber (D) J. Carter Thorne (D), Vandana Ahluwalia, Jennifer Burt, Diane Lacaille, \\ Deborah A. Marshall $\mathbb{D}^{\mathbb{D}}$, Glen S. Hazlewood, Dianne Mosher, Lisa Denning, Ildiko Szamko, \\ Ricky Chin, Sean Hamilton, Susanne Benseler, Marinka Twilt, Natalie J. Shiff, Vivian Bykerk, \\ Joanne Homik, and Cheryl Barnabe (D)
}

\begin{abstract}
Objective. To test the feasibility of reporting on 4 national performance measures for patients with rheumatoid arthritis (RA) in 5 different models of care.

Methods. The following performance measures were evaluated in 5 models of care: waiting time (WT) to rheumatologist consultation, percentage of patients seen in yearly followup (FU), percentage taking disease-modifying antirheumatic drugs (DMARD), and time to starting DMARD. All models aimed to improve early access and care for patients with RA.

Results. A number of feasibility issues were encountered in performance measure evaluation because of differences in site data collection and/or the duration of the model of care. For example, while 4/5 programs maintained clinical or research databases, chart reviews were still required to report on WT. Median WT for care in 2015 varied by site between 21 and 75 days. Yearly FU rates could only be calculated in 2 sites (combined owing to small numbers) and varied between $83 \%$ and $100 \%$. Percentage of patients taking a DMARD and time to DMARD could be calculated in 3 models, and rates of DMARD use were between $90 \%$ and $100 \%$, with median time to DMARD of 0 days in each. Conclusion. Our review has shown that even in models of care designed to improve access to care and early treatment, data to document improvements are often lacking. Where data were available for measuring, deficits in WT performance were noted for some centers. Our results highlight a need to improve reporting processes to drive quality improvement. (First Release June 15 2018; J Rheumatol 2018;45:1501-8; doi:10.3899/jrheum.171284)
\end{abstract}

Key Indexing Terms:

RHEUMATOID ARTHRITIS QUALITY OF HEALTHCARE QUALITY INDICATORS

From the departments of Medicine and Community Health Sciences, University of Calgary, Calgary, Alberta; Arthritis Research Canada, Richmond, British Columbia, Canada.

Funding provided by a grant from the Canadian Initiative for Outcomes in Rheumatology Care.

C.E. Barber, MD, PhD, FRCPC, Assistant Professor, Division of Rheumatology, Department of Medicine, and the Department of Community Health Sciences, University of Calgary, Cumming School of Medicine, and Research Scientist, Arthritis Research Canada; J.C. Thorne, MD, FRCPC, Assistant Professor, University of Toronto, and Medical Director, The Arthritis Program at Southlake Regional Health Centre; V. Ahluwalia, MD, FRCPC, Consultant Rheumatologist, William Osler Health System; J. Burt, Physiotherapist, Advanced Clinician Practitioner in Arthritis Care (ACPAC) program-trained Extended Role Practitioner (ERP), Rheumatology Services, St. Clare's Mercy Hospital, Eastern Health; D. Lacaille, MD, FRCPC, MHSc, Mary Pack Chair in Arthritis Research, Professor, Division of Rheumatology, Department of Medicine, University of British Columbia, and Senior Scientist, Arthritis Research Canada; D.A. Marshall, PhD, Professor, Department of Community Health Sciences, Cumming School of Medicine, Canada Research Chair (Health Services and Systems Research), Arthur J.E. Child Chair in Rheumatology Research, Department of Medicine, University of Calgary, and McCaig Institute for Bone and Joint Health; G.S. Hazlewood, MD, PhD, FRCPC, Assistant Professor, Division of Rheumatology, Department of Medicine, and the Department of Community Health Sciences,

University of Calgary, Cumming School of Medicine, and Research

Scientist, Arthritis Research Canada; D. Mosher, MD, FRCPC, Professor,
Rheumatology Division Head, Department of Medicine, Cumming School of Medicine, University of Calgary; L. Denning, Physiotherapist, ACPAC program-trained ERP, William Osler Health System; I. Szamko, The Arthritis Program, Southlake Regional Health Centre; R. Chin, MSc, Division of Rheumatology, Department of Medicine, Cumming School of Medicine, University of Calgary; S. Hamilton, MD, FRCPC, Associate Professor of Medicine, Rheumatology Division Chief, St. Clare's Mercy Hospital, Memorial University of Newfoundland; S. Benseler, MD, PhD, Professor, Section Chief, Pediatric Rheumatology, Department of Pediatrics, Cumming School of Medicine, University of Calgary; M. Twilt, MD, MSCE, PhD, Assistant Professor, Pediatric Rheumatology, Department of Pediatrics, Cumming School of Medicine, University of Calgary; N.J. Shiff, MD, MHSc, Associate Professor, Department of Pediatrics, University of Florida, and adjunct professor, Department of Community Health and Epidemiology, University of Saskatchewan; V. Bykerk, MD, FRCPC, Associate Professor of Medicine, Cornell University, and Associate Scientist, Division of Rheumatology, Hospital for Special Surgery; J. Homik, MD, MSc, FRCPC, Associate Professor, Department of Medicine, University of Alberta; C. Barnabe, MD, MSc, FRCPC, Associate Professor, departments of Medicine and Community Health Sciences, University of Calgary, and Research Scientist, Arthritis Research Canada.

Address correspondence to Dr. C.E. Barber, Division of Rheumatology, University of Calgary, HRIC 3AA20, 3280 Hospital Drive NW, Calgary, AlbertaT2N 4Z6, Canada.E-mail: cehbarbe@ucalgary.ca

Accepted for publication March 2, 2018.

\section{Personal non-commercial use only. The Journal of Rheumatology Copyright @ 2018 . All rights reserved.}


Early and targeted treatment strategies in rheumatoid arthritis (RA) have been shown to dramatically improve patient outcomes, reducing disease activity and improving functional status ${ }^{1,2}$. This model of early and targeted treatment is concordant with national ${ }^{3}$ and international ${ }^{4,5}$ RA guidelines. The achievement of these targets relies heavily on appropriate and effective models of care $^{6}$, seen as the structuring of health services in a center, region, province, or nation, to ensure appropriate service provision and to prioritize identification of new cases of inflammatory arthritis, especially in the setting of limited provider resources ${ }^{7}$. While access to care is a key facet of many models of care and is the focus of the current work, the Arthritis Alliance of Canada's (AAC) Pan-Canadian Approach to Inflammatory Arthritis Models of Care $^{8}$ highlights that model of care should encompass the continuum of care from early diagnosis, treatment, through to ongoing and shared care.

A vital part of the AAC's approach was the development of an evaluation framework for models of care ${ }^{9}$, to report on the success of a model of care. The AAC framework includes a set of 6 system-level performance measures that were rigorously developed to measure model of care performance with a focus on access to care and early treatment ${ }^{10}$.

Across Canada, many rheumatology centers have developed programs to improve access to care ${ }^{8,11,12,13,14}$. The objective of our study was to evaluate the feasibility of reporting on 4 of the performance measures in RA [time to rheumatologist consultation, percentage of patients seen yearly by rheumatologists, percentage of patients taking disease-modifying antirheumatic drugs (DMARD) therapy, and time to DMARD start] using clinic-level and/or triage data from 5 clinical sites. Two measures were not evaluated: percentage of patients with inflammatory arthritis seen (because that relies on administrative data), and rheumatologists per capita, because that is explored elsewhere ${ }^{7}$.

\section{MATERIALS AND METHODS}

Performance measures were assessed in 5 clinical sites, using data between 2013 and 2016 (depending on the start date of the site model and the availability of data). The data used were exclusively from triage or cohort databases from each site, supplemented with minimal chart reviews directed at confirming diagnosis and/or one or more dates required for performance measure calculation. Detailed information about patient demographics or care was not collected, because the primary objective of the study was to assess the feasibility of measure reporting.

Location of included sites. Each site had improved access to care and treatment for patients with early inflammatory arthritis as central model objectives. Sites included in the study represent a convenience sample and were selected based on willing local champions to test the measures. All site leads had participated in the measure development process. Table 1 describes each site: The Rheumatic Health Unit (RHU) Central Triage Model of Care at the St. Clare's Mercy Hospital in St. John's, Newfoundland; The Arthritis Program (TAP) at the Southlake Regional Hospital in Newmarket, Ontario; The Early Arthritis Clinic (EAC) at the William Osler Health System in Brampton, Ontario; the Siksika Arthritis Screening Project (SASP) on the Siksika Reserve in Alberta ${ }^{15}$; and the Urban Aboriginal Arthritis Care Program (UAACP) at the Elbow River Healing Lodge in Calgary, Alberta ${ }^{16}$.
Data from the 2 indigenous sites were pooled for analysis owing to small numbers. The sites were selected as test sites for evaluating the performance measures because they represented different types of models of care, provided representation of practices in different provinces, and had willing champions who had been part of the original development of the measures. Our study is part of a larger study evaluating the performance measures using different data sources, including administrative and electronic medical record data.

Assessment of the feasibility of performance measure reporting. Meetings were held with the leads of each site to discuss the data available to report on each performance measure as well as resources available for continuous reporting. At a minimum it was decided that chart reviews would be used, if necessary, to determine the waiting time measure. If other measures were not feasible to report without extensive chart reviews, then they would not be reported, and this would be noted as part of feasibility testing and rectified in future data collection if desired by the site.

Patient inclusion and exclusion criteria. Sequential RA cases over the study period were included at each site, using the treating rheumatologist's RA diagnosis for inclusion. However, for the TAP site, only patients enrolled in a national early arthritis cohort (the Canadian early Arthritis CoHort, $\mathrm{CATCH}^{17}$ ) were included. At other sites, limited chart reviews were conducted to confirm RA diagnosis, with the exception of the 2 indigenous arthritis care sites, because these data were available. Cases seen in the emergency room, self-referrals, and transfers of care were excluded from measurement of waiting times for care.

Measure calculation. Calculation of the performance measures has previously been described ${ }^{10,18}$. In brief, for the waiting time measure, median and 90th percentile waiting times in days (d) for rheumatologist care was calculated by measuring the time between referral receipt and the first visit to the rheumatologist for patients with a confirmed diagnosis of RA (confirmed before, at, or after that first visit). The percentage of cases meeting a benchmark of $<4$ weeks was also calculated.

The percentage of patients seen in yearly followup by rheumatology was reported by calendar year. Each patient's followup time began at their initial visit and continued until the last available followup, or the patient was lost to followup, whichever came first. The proportion of patients meeting this measure was calculated using the denominator (e.g., expected visits: 1 for each calendar year), and whether there was at least 1 observed visit in the calendar year as the numerator. If patients had less than 1 year of followup, they were excluded from the analysis for the measure because performance could not be determined. Similarly, if there was not a complete year of available followup for the final year of measurement, patients were excluded from the denominator of the final year. The number of gaps in care of $>12$ and $>14$ months between 2 consecutive visits was also calculated and reported for the duration of total followup for all patients in the cohorts.

The percentage of patients who received a traditional DMARD, biologic DMARD, or small-molecule inhibitor at least once during the measurement year was calculated between the baseline date (enrollment date) and end of followup date on a yearly basis for each patient. The denominator included all patients still in the cohort at the end of the measurement year and the numerator included all patients with at least 1 traditional DMARD, biologic DMARD, or small-molecule inhibitor prescription during the year. Patients were excluded from the denominator in years in which they had a documented contraindication to DMARD use (e.g., pregnancy or concomitant malignancy) or a documented patient refusal of treatment.

The time to DMARD therapy was calculated by measuring the time between the physician-reported date of RA diagnosis and the date of first DMARD start. The median and 90th percentiles were reported. Additionally, the percentage of patients treated within the benchmark of 14 days was also reported. For this measure, patients with a missing diagnosis date were excluded.

Ethics. Ethical approval for the study was obtained at each individual site. In particular, the indigenous cohorts adhere to research ethics with indigenous populations and respect OCAP principles (Ownership, Control,

Personal non-commercial use only. The Journal of Rheumatology Copyright @ 2018 . All rights reserved. 
Table 1. Descriptions of the 5 models of care included in the study.

\begin{tabular}{|c|c|c|c|}
\hline Model of Care & General Description & Database & Funding \\
\hline $\begin{array}{l}\text { The Rheumatic Health Unit } \\
\text { (RHU) Central Triage Model of } \\
\text { Care, St. Clare's Mercy Hospital, } \\
\text { St. John's, Newfoundland } \\
\text { and Labrador }\end{array}$ & $\begin{array}{l}\text { Central model of access for } \\
\text { rheumatology services since } \\
\text { 2011, funding for an interprofessional } \\
\text { approach in } 2014.2 \mathrm{NP}, 1 \mathrm{PT}, 1 \mathrm{OT}, 3 \\
\text { rheumatologists, } 1 / 4 \text { pharmacist. } \\
\text { Provincial referral site for adult } \\
\text { rheumatology in Newfoundland. }\end{array}$ & Central triage database available & $\begin{array}{l}\text { DHCS and EH pilot funding } \\
\text { 2011-2014, permanent funding } 2014\end{array}$ \\
\hline $\begin{array}{l}\text { The Arthritis Program (TAP), } \\
\text { Southlake Regional Hospital, } \\
\text { Newmarket, Ontario }\end{array}$ & $\begin{array}{l}\text { Interprofessional team-based approach } \\
\text { to assessment, treatment, and education } \\
\text { of patients with arthritis since } 1991 . \\
\text { Catchment area: York, Simcoe, } \\
\text { Muskoka/Parry Sound }\end{array}$ & $\begin{array}{l}\text { Data from } 2 \text { rheumatologists only } \\
\text { included; no triage database available }\end{array}$ & $\begin{array}{l}\text { TAP awarded MOH grant in } 1991 \text {, } \\
\text { subsequently rolled into the Hospital } \\
\text { Global Budget }^{1}\end{array}$ \\
\hline $\begin{array}{l}\text { The Early Arthritis Clinic (EAC), } \\
\text { William Osler Health System, } \\
\text { Brampton, Ontario }\end{array}$ & $\begin{array}{l}\text { Central model of access for early } \\
\text { inflammatory arthritis since } 2014 . \\
\text { Four rheumatologists and } 1 \text { ACPAC } \\
\text { ERP PT. Catchment area: Brampton, } \\
\text { Etobicoke, and surrounding Greater } \\
\text { Toronto areas }\end{array}$ & Central triage database available & $\begin{array}{l}\text { WOHS Global Budget through } \\
\text { MSK program, set up in } 2014 \text {. }\end{array}$ \\
\hline $\begin{array}{l}\text { The Siksika Arthritis Screening } \\
\text { Project (SASP), Siksika Reserve, } \\
\text { Alberta }\end{array}$ & $\begin{array}{l}\text { On-reserve arthritis clinic since } 2011 \text {; } \\
\text { indigenous patients can use self-referral } \\
\text { to remove barriers to access to care. } \\
\text { A single rheumatologist leads this } \\
\text { model of care. }\end{array}$ & Cohort data collected & $\begin{array}{l}\text { Physician salary from ARP, } \\
\text { clinic funded through tripartite } \\
\text { agreement between First Nations } \\
\text { and Inuit Health, AHS, and } \\
\text { Siksika Nation. }\end{array}$ \\
\hline $\begin{array}{l}\text { The Urban Aboriginal Arthritis } \\
\text { Care Program (UAACP), } \\
\text { Calgary, Alberta }\end{array}$ & $\begin{array}{l}\text { Clinic for urban indigenous population } \\
\text { since 2012; patients can use self- } \\
\text { referral to remove barriers to access to care. } \\
\text { A single rheumatologist leads } \\
\text { this model of care. }\end{array}$ & Cohort data collected & $\begin{array}{l}\text { Physician salary from ARP, } \\
\text { clinic funded by AHS. }\end{array}$ \\
\hline
\end{tabular}

${ }^{1}$ Hospital Global Budget: York County Hospital, now Southlake Regional Health Centre. NP: nurse practitioner; PT: physiotherapist; OT: occupational therapist; DHCS: Department of Health and Community Services, Government of Newfoundland and Labrador; EH: Eastern Health; MOH: Ministry of Health; ACPAC ERP: Advanced Clinician Practitioner in Arthritis Care Extended Role Practitioner; WOHS: William Osler Health System; ARP: Alternative Relationship Plan; AHS: Alberta Health Services; MSK: musculoskeletal.

Access, and Possession). OCAP is a registered trademark of the First Nations Information Governance Centre ${ }^{19}$. The overall study was approved by the University of Calgary Research Ethics Board (REB15-2271).

\section{RESULTS}

Feasibility of reporting on each performance measure. There were a number of feasibility issues encountered in the evaluation of the performance measures as a result of variations in data collected by site (Table 2). Four of the sites had databases (2 triage databases and 2 cohort databases); however, in all 5 sites chart reviews were necessary to gather data for the waiting time measure ( $3 / 5$ missing diagnosis and $3 / 5$ missing referral dates). Because data were limited owing to the recent start of the care model in 2 sites (EAC and RHU data collection for sites commenced in 2014), the evaluating percentage seen in yearly followup was determined not to be feasible to report. At a third site, TAP, longitudinal chart reviews over the entire study duration were determined to be too cumbersome, leaving only the SASP and UAACP models of care reporting on this measure. Only 3 models of care (EAC, SASP, UAACP) had readily available treatment data that could be used to report on the percentage of patients taking a DMARD and time to DMARD start performance measures.

Waiting times of patients for rheumatology consultation. Waiting times for rheumatology consultation for patients subsequently diagnosed with RA were calculated and varied by site (Table 3). To illustrate, in 2015 the median waiting time varied between sites from 21 days to 75 days and the 90th percentile was between 57 and 137 days. There were limited data on the longitudinal trends of waiting times at model sites because of their recent inception; however, data were available from TAP between 2013 and 2015. This showed a trend to improvement in waiting times from a median of 37 days to 21 days and the percentage meeting the 4 -week benchmark increased from $29 \%$ to $64 \%$. The TAP site was also the only one with a median wait time below the benchmark of 28 days (by 2015). It should be noted that as described in Table 1, 36\% of SASP and UAACP patients self-referred to the programs and this was an exclusion criterion for performance reporting (indeed, in 2011 self-referral was the only mode of referral and this year was entirely excluded from reporting). Also, owing to small

Personal non-commercial use only. The Journal of Rheumatology Copyright $\odot$ 2018. All rights reserved. 
Table 2. Feasibility of measuring 4 performance measures in 5 models of care.

\begin{tabular}{|c|c|c|c|c|c|c|c|c|}
\hline $\begin{array}{l}\text { Model of } \\
\text { Care }\end{array}$ & $\begin{array}{c}\text { Final } \\
\text { Diagnosis } \\
\text { Available }\end{array}$ & $\begin{array}{l}\text { Referral } \\
\text { Date } \\
\text { Available }\end{array}$ & $\begin{array}{c}\text { Visit } \\
\text { Dates } \\
\text { Available }\end{array}$ & $\begin{array}{l}\text { ata Elements } \\
\text { Length of } \\
\text { Followup }^{1}\end{array}$ & $\begin{array}{l}\text { s Required } f \\
\text { Treatment } \\
\text { Data } \\
\text { Available }\end{array}$ & $\begin{array}{l}\text { Evaluation of Performance Mea } \\
\text { Other }\end{array}$ & ures & $\begin{array}{c}\text { Performance } \\
\text { Measures Reported }\end{array}$ \\
\hline RHU & No & Yes & Yes & Limited & No & $\begin{array}{l}\text { Triage database captured } \\
\text { diagnosis to first point of } \\
\text { entry (often allied health } \\
\text { provider) }\end{array}$ & $\begin{array}{l}\text { Chart reviews to } \\
\text { determine diagnosis }\end{array}$ & $\begin{array}{l}\text { Waiting times for } \\
\text { consultation }\end{array}$ \\
\hline EAC & No & Yes & Yes & Limited & Yes & N/A & $\begin{array}{l}\text { Chart reviews to } \\
\text { determine diagnosis }\end{array}$ & $\begin{array}{l}\text { Waiting times for } \\
\text { consultation, percent } \\
\text { taking DMARD, time } \\
\text { to DMARD }\end{array}$ \\
\hline
\end{tabular}

\footnotetext{
1 "Limited" followup meant that performance measures relating to the percent of patients seen in yearly followup could not be calculated because either the length of operation of the model of care was not $>1$ year, or the data were not readily available without an extensive chart review. "Adequate" refers to models where there were enough years of data and the data available to report on this measure. ${ }^{2}$ The patients from TAP were enrolled in an early arthritis cohort, and performance measures for total cohort are reported elsewhere for the other 3 performance measures but were not readily available with the data sources in clinic. ${ }^{3}$ The numbers of patients in these models of care resulted in cell sizes $<5$ for reporting for some years, so the data were pooled for reporting. Additionally, similar data were available for both models of care because the cohorts were started by the same investigator (C. Barnabe). DMARD: disease-modifying antirheumatic drug; EAC: Early Arthritis Clinic at the William Osler Health System in Brampton, Ontario; RHU: Rheumatic Health Unit at St. Clare's Mercy Hospital, St. John's, Newfoundland; SASP: Siksika Arthritis Screening Project on the Siksika Reserve, Alberta; TAP: The Arthritis Program at the Southlake Regional Hospital in Newmarket, Ontario; UAACP: Urban Aboriginal Arthritis Care Program in Calgary, Alberta; N/A: not applicable.
}

Table 3. Waiting times for rheumatology consultation in 4 models of care.

\begin{tabular}{|c|c|c|c|c|c|c|c|c|c|c|c|c|}
\hline \multirow{2}{*}{$\begin{array}{l}\text { Model of } \\
\text { Care }\end{array}$} & \multirow[b]{2}{*}{$\mathrm{N}$} & \multicolumn{3}{|c|}{ Waiting Times for 2013} & \multirow[b]{2}{*}{$\mathrm{N}$} & \multicolumn{3}{|c|}{ Waiting Times for 2014} & \multicolumn{3}{|c|}{ Waiting Times for 2015} & \multirow[b]{2}{*}{$\begin{array}{c}\% \text { Meeting } \\
\text { Benchmark } \\
\text { of } \leq 4 \\
\text { Weeks }\end{array}$} \\
\hline & & $\begin{array}{l}\text { Median, } \\
\text { Days }\end{array}$ & $\begin{array}{l}\text { 90th } \\
\text { Percentile, } \\
\text { Days }\end{array}$ & $\begin{array}{c}\text { Percent } \\
\text { Meeting } \\
\text { Benchmark } \\
\text { of } \leq 4 \text { Weeks }\end{array}$ & & $\begin{array}{c}\text { Median, } \\
\text { Days }\end{array}$ & $\begin{array}{l}\text { 90th } \\
\text { Percentile, } \\
\text { Days }\end{array}$ & $\begin{array}{c}\text { Percent } \\
\text { Meeting } \\
\text { Benchmark } \\
\text { of } \leq 4 \text { Weeks }\end{array}$ & $\mathrm{N}$ & $\begin{array}{c}\text { Median, } \\
\text { Days }\end{array}$ & $\begin{array}{c}\text { 90th } \\
\text { Percentile, } \\
\text { Days }\end{array}$ & \\
\hline RHU & $\mathrm{N} / \mathrm{A}^{1}$ & $\mathrm{~N} / \mathrm{A}^{1}$ & $\mathrm{~N} / \mathrm{A}^{1}$ & $\mathrm{~N} / \mathrm{A}^{1}$ & 60 & 143 & 201 & 8 & 72 & 75 & 137 & 11 \\
\hline TAP & 31 & 37 & 68 & 29 & 29 & 34 & 85 & 31 & 25 & 21 & 57 & 64 \\
\hline $\mathrm{UAACP}^{3}$ & - & - & - & - & - & - & - & - & 16 & 30 & 178 & 44 \\
\hline
\end{tabular}

${ }^{1}$ Only 1 site had conducted its model of care during $2013 .{ }^{2}$ The EAC did not have complete data for 2014 (only half a year available). ${ }^{3}$ The indigenous models of care (SASP and UAACP) had high rates of self-referral (36\%), leading to many excluded cases (including all for the year 2011). Additionally, because of small cell sizes $(<5)$ in 3 out of 4 available years of data, only the overall waiting times between the years 2012 and 2015 are reported. EAC: Early Arthritis Clinic at the William Osler Health System in Brampton, Ontario; RHU: Rheumatic Health Unit at St. Clare's Mercy Hospital, St. John's, Newfoundland; SASP: Siksika Arthritis Screening Project on the Siksika Reserve, Alberta; TAP: The Arthritis Program at the Southlake Regional Hospital in Newmarket, Ontario; UAACP: Urban Aboriginal Arthritis Care Program in Calgary, Alberta; N/A: not applicable.

numbers of new patients with RA per year (cell sizes $<5$ for 3 of the 4 potential reporting years), only the overall waiting times for 2012 to 2015 are reported (as opposed to yearly waiting times; Table 3).
Percentage of patients with RA seen in yearly followup. As described above, the only sites with available data on yearly followup rates were the SASP and UAACP models of care. In the 2 sites combined, there were 66 prevalent RA cases 
and 50 with followup data over a mean measurement period of $32.6 \pm 19.5$ months. A total of 5 patients had followup shorter than 1 year and were also excluded from measurement, leaving 45 prevalent RA cases with followup data. Yearly followup rates in the cohorts were excellent: between 83 and $100 \%$. This is also reflected in the analysis of the number of gaps in care (reported on all 50 prevalent cases, Table 4). Over half of all patients (56\%) had no gaps of $>12$ months between visits and $64 \%$ had no gaps of $>14$ months. There were 18 patients (36\%) with 1 gap of $>12$ months and $15(30 \%)$ with 1 gap of $>14$ months; < 5 patients had 2 or more gaps in care $>12$ months.

Percentage of patients taking a DMARD and time to DMARD start. The percentage of patients taking a DMARD and time to DMARD start were readily calculated at 3 sites: SASP, UAACP (Table 5), and EAC (Table 6). In the SASP and UAACP sites there were 66 prevalent RA cases; however, 2 cases met exclusion criteria owing to concomitant contraindications for DMARD use during certain measurement years and an additional 5 had a documented decline of a DMARD prescription and are excluded from the measurement years in which they declined treatment. Overall rates of DMARD treatment were high (range 90-100\% between 2011 and 2016; Table 5). In the SASP and UAACP sites, time to DMARD therapy for patients with new-onset RA was calculated on 30 patients with incident RA. Yearly reporting of this performance measure was not possible because of small sample sizes $(<5)$ in 2 of the 5 years of available data. Between 2011 and 2015 the median time between RA diagnosis and DMARD prescription was 0 days (indicating treatment prescription occurred at the time of diagnosis); however, the 90th percentile was 59.5 days. Overall, $87 \%$ of patients (26/30) were prescribed DMARD within 2 weeks of diagnosis.

Table 4. Percentage of prevalent RA cases $\left(n=45^{1}\right)$ seen in yearly followup in 2 indigenous models of care.

\begin{tabular}{|c|c|c|c|c|c|c|}
\hline & 2011 & 2012 & 2013 & 2014 & 2015 & 2016 \\
\hline Observed & NR & 9 & 19 & 24 & 31 & 29 \\
\hline Expected & NR & 9 & 23 & 28 & 34 & 29 \\
\hline \multicolumn{7}{|c|}{ Gaps in care $>12$ mos over followup (total $n=50$ ) } \\
\hline No. gaps & 0 & 1 & 2 & 3 & & \\
\hline $\mathrm{N}(\%)$ & $28(56)$ & $18(36)$ & NR & NR & & \\
\hline
\end{tabular}

NR due to cell sizes $<5 .{ }^{1}$ While there were 66 prevalent RA cases in the indigenous cohorts, 16 had no followup information and were excluded from the measure. An additional 5 patients were also excluded from yearly followup reporting because they had their first and second visits within a single calendar year and then were lost to followup (they are included in the analysis of gaps in followup in the lower half of the table). RA: rheumatoid arthritis; NR: not reportable; N/A: not applicable.

Table 5. Percentage of rheumatoid arthritis patients taking DMARD in the SASP and UAACP cohorts ${ }^{1}$.

\begin{tabular}{|c|c|c|c|c|c|c|}
\hline Year & 2011 & 2012 & 2013 & 2014 & 2015 & 2016 \\
\hline Observed & 10 & 25 & 28 & 34 & 30 & 9 \\
\hline Expected & 11 & 27 & 29 & 35 & 30 & 10 \\
\hline
\end{tabular}

${ }^{1}$ The 2 indigenous cohorts included SASP and UAACP. The results are combined owing to small numbers in some cells. It was also not possible to report on time to DMARD start in some years because of small sample sizes $(\mathrm{n}<5)$ for patients starting DMARD. DMARD: disease-modifying antirheumatic drugs; SASP: Siksika Arthritis Screening Project on the Siksika Reserve, Alberta; UAACP: Urban Aboriginal Arthritis Care Program in Calgary, Alberta.

Table 6. Percentage of RA patients taking DMARD and time to DMARD start in the EAC.

\begin{tabular}{|c|c|c|c|c|c|}
\hline 2015 & 77 & 100 & 0 & 0 & 94 \\
\hline
\end{tabular}

${ }^{1}$ The EAC did not have complete data for 2014 (only half a year available from June to December of 2014). ${ }^{2}$ Data were available on documented refusals of DMARD, which were excluded in the denominator for this measure. There were 2 refusals (8\%) in 2014 and 3 refusals (4\%) in 2015. RA: rheumatoid arthritis; DMARD: disease-modifying antirheumatic drugs; EAC: Early Arthritis Clinic at the William Osler Health System in Brampton, Ontario. 
In the EAC clinic, data were available since the start of the clinic in June 2014 until the end of 2015 (Table 6). During both years, the median days between diagnosis and DMARD prescription was 0 , as was the 90th percentile. The majority ( $92 \%$ and $94 \%$ ) of patients were treated within the 2 -week benchmark in 2014 and 2015, respectively, and after excluding patients with documented refusals, $100 \%$ of eligible patients were treated with DMARD.

\section{DISCUSSION}

In our study, we provide the assessment of feasibility of measuring system-level performance measures, and report on adherence to 4 of the performance measures in 5 sites. As we have illustrated, even in models designed to improve access to care for early inflammatory arthritis, all the data required to measure and report on the success of these programs are not routinely collected. Variations in reporting of critical data elements, such as the availability of final diagnosis, referral and visit date information, and treatment information, highlight challenges in measure reporting.

Where data were available, our study also highlights significant disparities in waiting times across sites, with many not meeting benchmarks. Reasons for delays in rheumatologist consultation may be complex and not necessarily within the control of the rheumatologist's office. In particular, long waiting times for patients with RA were observed in Newfoundland. The St. John's RHU Central Triage Model is new (started in 2011 as a pilot project, and permanent funding for an interprofessional model of care was achieved in 2014) and it is possible that a decline in waiting times for care may happen over time. It is also possible that given the low number of rheumatologists per capita in the province ${ }^{7}$, additional resources are needed to meet the demand for timely rheumatology services.

Interestingly, some of the sites had a first point of contact with an allied health professional (AHP; RHU, EAC, and many TAP patients) and in some cases data were available on the wait time to this first point of contact (although this was not the focus of our study). For example, at the EAC site in 2015, 79 patients saw the AHP prior to a visit with a rheumatologist ( $99 \%$ of patients), and median time to the AHP was 32 days, with a 90th percentile of 100 days (compared with a median of 45 days and a 90th percentile of 83 days for rheumatologist consultation). It is unclear, because data collection was started after this model of care was implemented, whether first contact with an AHP has decreased overall waiting times for patients with inflammatory arthritis. The EAC model of care team estimates that twice as many patients were screened to find eligible patients with suspected RA for the clinic, which likely shortened overall waiting times for these patients. Similar models of AHP screening have been implemented in 2 of the other sites we evaluated (RHU and TAP) and a similar phenomenon of shorter waiting times for AHP review was also observed at
TAP (data not available for RHU). Further study of the effect of having an AHP as a first contact, and ongoing monitoring of the effect on waiting times at these sites, are recommended but were not the objectives of the current project.

Waiting times in the 2 sites serving indigenous populations in Alberta were challenging to report on as a component of the model of care was self-referral (which was an exclusion criterion for reporting). This should not be taken as an indication of "timely" diagnosis because it is still possible that patients may have had prolonged symptoms and/or multiple healthcare barriers ${ }^{20}$ before seeking care, leading to a delay in diagnosis and/or treatment. Indeed, evidence from Alberta $^{21,22}$, other provinces in Canada ${ }^{23}$, and around the world ${ }^{24}$ suggests a high burden of arthritis among indigenous populations as well as disparities in patient outcomes ${ }^{22,25}$. Thus, waiting times for consultation will need to be examined in closer detail.

While we were hoping that all performance measures could be reported at each site, this was a challenge owing to the available data collected by the models of care and/or the length of time the sites had been operational. Currently there is no funding for any of the models of care to routinely collect and report on these important metrics. Available data on the DMARD measures collected from 2 cohorts suggest high levels of treatment with DMARD and low waiting times to DMARD starts, with a majority of patients treated at the time of diagnosis by a rheumatologist. This finding is in keeping with other studies ${ }^{18}$. However, the lack of delay between rheumatologist diagnosis and starting DMARD should not be interpreted as timely treatment with DMARD, because waiting times between symptom onset and DMARD start may be longer and suboptimal, as previously found in other studies $^{26}$.

Percentage of patients seen in yearly followup could only be evaluated in the SASP and UAACP cohorts with results combined because of low numbers. Followup rates were excellent and comparable with rates of annual followup recently evaluated in the $\mathrm{CATCH}$ cohort ${ }^{18}$. One potential issue that may not be adequately addressed by the performance measure is attrition from patient factors unrelated to quality of care (e.g., moving away or withdrawing consent). In our analysis, we excluded a small number of patients who dropped out within the first year of cohort entry or had less than 1 year of followup by study end, because it was possible they had moved away or withdrawn consent for followup. For this reason, removal may have inflated performance on the measures, during the first year of expected followup.

While this is the first study, to our knowledge, looking at the feasibility of reporting on recently developed system-level performance measures using triage or clinic data available from multiple sites, there are a number of limitations to this work. As noted, performance measures could not be reported for all sites because data were lacking. In the

Personal non-commercial use only. The Journal of Rheumatology Copyright (C) 2018. All rights reserved. 
future, we recommend that models of care directed at improving access to care and early treatment routinely receive funding to collect basic data including the date referrals were received, date of visits (including to rheumatologist and/or AHP), date of DMARD start, and final diagnosis. While the majority of the data we included was on consecutive patients, it should also be highlighted that the TAP site included patients already participating in an early arthritis cohort study (this was how we were able to identify RA cases, because no other data source was readily available). The site does try to include all early RA cases in CATCH; however, it is unclear whether those patients recruited could have differed in their waiting times or in performance of other measures from patients not included, or whether the study protocol could have influenced care. The numbers of sites included in this study was also small (n $=5$ ), with low numbers of patients at many sites, and results may not be representative of other centers or provincial performance on the measures. Lastly, because the focus of the study was to assess the feasibility of measurement, additional details about each cohort were not recorded, including potential predictors of poor adherence to the measures. For example, seronegative cases or those with very low disease activity may have longer waiting times than cases with very active disease. Examining predictors of performance on the measures as well as whether better performance improves longterm patient outcomes will be an important ongoing line of study.

This study has uncovered gaps in data collection that make it challenging to evaluate models of care promoting early access to care. While it is possible that these gaps are unique to the sites we selected, we suspect similar issues with data collection and reporting are likely present in other jurisdictions in Canada, because reporting on quality metrics is currently not mandated. We recommend instituting basic data collection and analysis to evaluate performance when new models of care are initiated, and this should be included in the funding model. Such data can be helpful in monitoring successes as well as potential unintended consequences of a model of care, and can also be useful when advocating for resources including additional healthcare staff.

\section{ACKNOWLEDGMENT}

The authors acknowledge the help of Diane Tin, BSc Phm, Pharmacist, CATCH Liaison, The Arthritis Program at Southlake Regional Health Centre, Newmarket, Ontario; Tyler White, CEO, Siksika Health Services, Siksika Nation, Alberta; Lana Potts, MD, CCFP, Medical Director, Elbow Healing Lodge, Aboriginal Health Program, Alberta Health Services, Alberta; and Grishma Patel, Summer research associate, William Osler Health System, Brampton, Ontario.

\section{REFERENCES}

1. Goekoop-Ruiterman YP, de Vries-Bouwstra JK, Kerstens PJ, Nielen MM, Vos K, van Schaardenburg D, et al. DAS-driven therapy versus routine care in patients with recent-onset active rheumatoid arthritis. Ann Rheum Dis 2010;69:65-9.
2. Alemao E, Joo S, Kawabata H, Al MJ, Allison PD, Rutten-van Molken MP, et al. Effects of achieving target measures in rheumatoid arthritis on functional status, quality of life, and resource utilization: analysis of clinical practice data. Arthritis Care Res 2016;68:308-17.

3. Bykerk VP, Akhavan P, Hazlewood GS, Schieir O, Dooley A, Haraoui B, et al. Canadian Rheumatology Association recommendations for pharmacological management of rheumatoid arthritis with traditional and biologic disease-modifying antirheumatic drugs. J Rheumatol 2012;39:1559-82.

4. Smolen JS, Landewe R, Bijlsma J, Burmester G, Chatzidionysiou K, Dougados $\mathrm{M}$, et al. EULAR recommendations for the management of rheumatoid arthritis with synthetic and biological disease-modifying antirheumatic drugs: 2016 update. Ann Rheum Dis 2017;76:960-77.

5. Singh JA, Saag KG, Bridges SL Jr., Akl EA, Bannuru RR, Sullivan MC, et al. 2015 American College of Rheumatology Guideline for the Treatment of Rheumatoid Arthritis. Arthritis Rheumatol 2016;68:1-26.

6. Davidson P, Halcomb E, Hickman L, Philips J, Graham B. Beyond the rhetoric: what do we mean by a 'model of care'? Aust J Adv Nurs 2006;23:47-55.

7. Barber CE, Jewett L, Badley EM, Lacaille D, Cividino A, Ahluwalia $\mathrm{V}$, et al. Stand up and be counted: measuring and mapping the rheumatology workforce in Canada. J Rheumatol 2017;44:248-57.

8. Ahluwalia V, Frank C, Zummer M, Mosher DP. A pan-Canadian approach to inflammatory arthritis models of care. [Internet. Accessed May 1, 2018.] Available from: www.arthritisalliance.ca

9. Arthritis Alliance of Canada (AAC). Measurement framework for IA models of care. [Internet. Accessed May 1, 2018.] Available from: www.arthritisalliance.ca/en/measurement-framework-for-iamodels-of-care

10. Barber CE, Marshall DA, Mosher DP, Akhavan P, Tucker L, Houghton K, et al. Development of system-level performance measures for evaluation of models of care for inflammatory arthritis in Canada. J Rheumatol 2016;43:530-40.

11. Ahluwalia V, Thorne C, Bombardier C, Bensen B, Karasik A, Pavlova V, et al. Models of care. [Internet. Accessed May 1, 2018.] Available from: http://ontariorheum.ca/publications/ other-publications

12. Hazlewood GS, Barr SG, Lopatina E, Marshall DA, Lupton TL, Fritzler MJ, et al. Improving appropriate access to care with central referral and triage in rheumatology. Arthritis Care Res 2016;68:1547-53.

13. Carpenter T, Katz SJ. Review of a rheumatology triage system: simple, accurate, and effective. Clin Rheumatol 2014;33:247-52.

14. Passalent LA, Kennedy C, Warmington K, Soever LJ, Lundon K, Shupak R, et al. System integration and clinical utilization of the Advanced Clinician Practitioner in Arthritis Care (ACPAC) Program-Trained Extended Role Practitioners in Ontario: a two-year, system-level evaluation. Healthc Policy 2013;8:56-70.

15. Bell E, Leclercq SA, Mosher DP, El-Gabalawy H, White T, Fritzler $\mathrm{M}$, et al. Inflammatory arthritis treatment outcomes at a First Nations reserve rheumatology specialty clinic [abstract]. Arthritis Rheumatol 2014;66:S925.

16. Barnabe C, Lockerbie S, Erasmus E, Crowshoe L. Facilitated access to an integrated model of care for arthritis in an urban Aboriginal population. Can Fam Physician 2017;63:699-706.

17. Bykerk VP, Jamal S, Boire G, Hitchon CA, Haraoui B, Pope JE, et al. The Canadian Early Arthritis Cohort (CATCH): patients with new-onset synovitis meeting the 2010 ACR/EULAR classification criteria but not the 1987 ACR classification criteria present with less severe disease activity. J Rheumatol 2012;39:2071-80.

18. Barber CEH, Schieir O, Lacaille D, Marshall DA, Barnabe C, Hazlewood G, et al. High adherence to system-level performance

Personal non-commercial use only. The Journal of Rheumatology Copyright (c) 2018. All rights reserved. 
measures for rheumatoid arthritis in a national early arthritis cohort over eight years. Arthritis Care Res 2018 Feb 16 (E-pub ahead of print).

19. First Nations Information Governance Centre (FNIGC): OCAP® [Internet. Accessed May 1, 2018.] Available from: http://fnigc.ca/ocap.html

20. Thurston WE, Coupal S, Jones CA, Crowshoe LF, Marshall DA, Homik J, et al. Discordant indigenous and provider frames explain challenges in improving access to arthritis care: a qualitative study using constructivist grounded theory. Int J Equity Health 2014;13:46.

21. Barnabe C, Jones CA, Bernatsky S, Peschken CA, Voaklander D, Homik $\mathrm{J}$, et al. Inflammatory arthritis prevalence and health services use in the First Nations and non-First Nations populations of Alberta, Canada. Arthritis Care Res 2017;69:467-74.

22. Barnabe C, Hemmelgarn B, Jones CA, Peschken CA, Voaklander D, Joseph L, et al. Imbalance of prevalence and specialty care for osteoarthritis for first nations people in Alberta, Canada. J Rheumatol 2015;42:323-8.

23. Barnabe C, Elias B, Bartlett J, Roos L, Peschken C. Arthritis in Aboriginal Manitobans: evidence for a high burden of disease. J Rheumatol 2008;35:1145-50.

24. McDougall C, Hurd K, Barnabe C. Systematic review of rheumatic disease epidemiology in the indigenous populations of Canada, the United States, Australia, and New Zealand. Semin Arthritis Rheum 2017;46:675-86.

25. Hurd K, Barnabe C. Systematic review of rheumatic disease phenotypes and outcomes in the Indigenous populations of Canada, the USA, Australia and New Zealand. Rheumatol Int 2017; 37:503-21.

26. Jamal S, Alibhai SM, Badley EM, Bombardier C. Time to treatment for new patients with rheumatoid arthritis in a major metropolitan city. J Rheumatol 2011;38:1282-8. 